\title{
PENGENALAN ALGORITMA PEMROGRAMAN MENGGUNAKAN APLIKASI SCRATCH BAGI SISWA SD 13 MATARAM
}

\author{
(Introduction to Algorithm and Programming using Scratch application for students \\ in SD 13 Mataram)
}

\author{
Ariyan Zubaidi ${ }^{[1]}$, Andy Hidayat Jatmika ${ }^{[1]}$, Wirarama Wedashwara ${ }^{[1]}$, Ahmad Zafrullah Mardiansyah ${ }^{[1,]}$ \\ ${ }^{[1]}$ Dept Informatics Engineering, University of Mataram \\ J1. Majapahit 62, Mataram, Lombok NTB, INDONESIA \\ Email: zubaidi13@unram.ac.id, [andy, wirarama, zaf]@unram.ac.id
}

\begin{abstract}
Abstrak
Perkembangan industri yang mengarah kepada industri 4.0 dimana komputer berperan penting di hampir semua aspek kehidupan, membawa kepada perlunya pengenalan dunia komputer khususnya pemrograman bagi anak-anak usia sekolah. Hal ini sebagai langkah awal mempersiapkan mereka menghadapi era industri 4.0. Namun masalah yang muncul adalah bagaimana memperkenalkan pemrograman dengan cara yang menyenangkan tanpa menghilangkan esensi apa yang akan disampaikan. Salah satu aplikasi yang dapat digunakan untuk mengajarkan pemrograman komputer untuk anak adalah adalah Scratch. Scratch dirancang dengan pendekatan bermain, belajar sendiri dan dilengkapi dengan animasi. Berbeda dengan bahasa pemrograman lainnya dengan basis teks, Scratch lebih menawarkan grafik untuk memudahkan memahami logika pemrograman kepada siswa. Ini memudahkan anak-anak untuk belajar pemrograman tanpa harus terpaku dengan berbagai penulisan sintaks dalam bahasa pemrograman. Kegiatan ini mengenalkan dan menjelaskan algoritma pemrograman pada anak usia tingkat dasar dengan bantuan aplikasi Scratch. Kegiatan ini dilakukan di Sekolah Dasar Negeri 13 Mataram. Kegiatan dilakukan dengan beberapa tahapan, yaitu memberikan penyuluhan tentang pentingny a menjaga protokol kesehatan Covid-19, pengisian kuesioner awal, pemberian materi pengenalan algoritma pemrograman disertai dengan penggunaan drone sebagai contoh, dan diakhiri dengan pengisian kuesioner akhir. Hasil kuesioner memperlihatkan ada peningkatan pengetahuan siswa dari sebelum dan sesudah dilaksanakan kegiatan ini. Dari 15 siswa, seluruhnya tidak mengerti algoritma dan pemrograman sebelum dilakukan kegiatan dan meningkat sebanyak 80\% mengerti setelah dilakukan kegiatan.
\end{abstract}

Keywords: Algoritma, Pemrograman, Scratch, Sekolah Dasar, Drone

\section{Pendahuluan}

Dunia Teknologi Informasi dan Komunikasi (TIK) saat ini merupakan bidang yang terus diminati. Tidak saja karena TIK dipandang 'keren' dan sedang tren saja, tetapi lebih pada berbagai manfaat nyata yang sudah dirasakan di berbagai bidang. Sekarang dan di masa yang akan datang, berbagai bidang kehidupan di dunia akan bergantung dengan penggunakan TIK. Hal inilah yang disebut dengan Industri 4.0, bagaimana di berbagai bidang kehidupan akan didukung oleh TIK sebagai tulang punggung berjalannya suatu bisnis atau usaha. Organisasi mulai dari yang berbasis profit maupun non-profit bergantung pada penggunaan TIK. Salah satu bagian penting yang berkaitan dengan TIK adalah pemrograman. Pemrograman adalah memprogram komputer dengan memberikan susunan instruksi dengan menggunakan bahasa pemrograman. Bagi mahasiswa informatika, istilah ini sudah tidak asing lagi. Namun, untuk dunia pendidikan pada umumnya, istilah ini belum banyak didengar. Sudah ada wacana bagaimana pembelajaran pemrograman di sekolah - sekolah diusulkan untuk dilaksanakan [1].

Pemrograman erat kaitannya dengan mahasiswa jurusan informatika. Ini mengacu pada anggapan bahwa pemrograman komputer didapatkan hanya pada bangku kuliah. Penelitian yang dilakukan oleh Microsoft menukkan sebanyak 91\% siswa Indonesia ingin tahu mengenai pemrograman. Sedangkan $72 \%$ malah ingin pemrograman diajarkan di sekolah mereka [2]. Jika masuk di kurikulum sekolah dasar, pembelajaran pemrograman tidak langsung mencetak programmer yang bisa mengembangkan aplikasi dan game, tetapi masih terbatas pada pengenalan dan membangkitkan bakat anak-anak yang mengarah kepada program komputer, sehingga di masa depan mereka dapat memperdalam ilmu menjadi programmer. Beberapa anak usia sekolah dasar di negara lain sudah lebih dulu memasukkan pembelajaran pemrograman dalam kurikulum belajarnya. Beberapa negara misalnya Singapura telah memulai untuk mengajarkannya sejak bangku sekolah dasar [3]. Amerika Serikat, Estonia, Inggris dan Finlandia 
juga telah mengajarkannya sejak usia sekolah dasar. Finlandia telah berhasil mencetak programmer-programmer handal dengan penanaman pemahaman sejak dini mengenai permrograman.

Masalah utama yang muncul jika pemrograman diajarkan sejak usia sekolah dasar adalah kecenderungan materi akan membosankan dan membuat siswa tidak tertarik. Hal ini dapat terjadi karena pemrograman nantinya akan banyak melibatkan kode-kode tertentu yang susah dimengerti. Perlu ada strategi yang dilakukan untuk membuat pembelajaran pemrograman tidak membosankan dan menarik untuk dipelajari. Hal ini yang dirasakan oleh guru di SD Negeri 13 Mataram, bagaimana menumbuhkan ketertarikan siswa terhadap dunia TIK dengan cara yang menarik melalui permainan-permainan yang lebih mudah diikuti dan dipraktikkan oleh siswa.

\section{TINJAUAN PUSTAKA}

Pemrograman adalah cara untuk memerintahkan komputer untuk melakukan suatu fungsi tertentu. Perintah komputer artinya menyediakan sekumpulan instruksi yang ditulis dengan bahasa yang dipahami oleh komputer. Sedangkan fungsi yang dinginkan mulai dari yang sederhana sampai yang kompleks [4]. Pemrograman adalah proses kreativitas dimana masing-masing orang memiliki kreativitas berbeda. Komputer tentu saja tidak mengerti dengan bahasa manusia, sehingga dibuat bahasa pemrograman yang dipahami oleh komputer [5]. Diperlukan metode yang menarik untuk dapat mengajarkan pemrograman terutama bagi usia anak-anak yang lebih suka bermain.

Salah satu aplikasi pemrograman komputer yang didesain khusus untuk anak usia 8 sampai 16 tahun adalah Scratch. Scratch merupakan bahasa pemrograman yang memudahkan penggunanya untuk membuat cerita, animasi, games, musik, dan seni secara interaktif [6]. Scratch merupakan bahasa pemrograman yang dikembangkan untuk anak-anak yang terdiri dari blok-blok kode yang berbeda dan grafik yang mudah untuk dipahami serta kemampuan menambahkan suara [7]. Scratch sudah digunakan pada siswa sekolah untuk membantu meningkatkan kreativitas berpikir matematis[8], selain itu dapat digunakan untuk mempelajari mekanika teknik [9], dan dapat membantu guru dalam mengimplementasikan pembelajaran inovatif [10].

\section{Metode Pengabdian Masyarakat}

Metode pelaksanaan kegiatan atau langkah-langkah yang akan dilakukan dalam kegiatan pengabdian kepada masyarakat ini diperlihatkan pada gambar

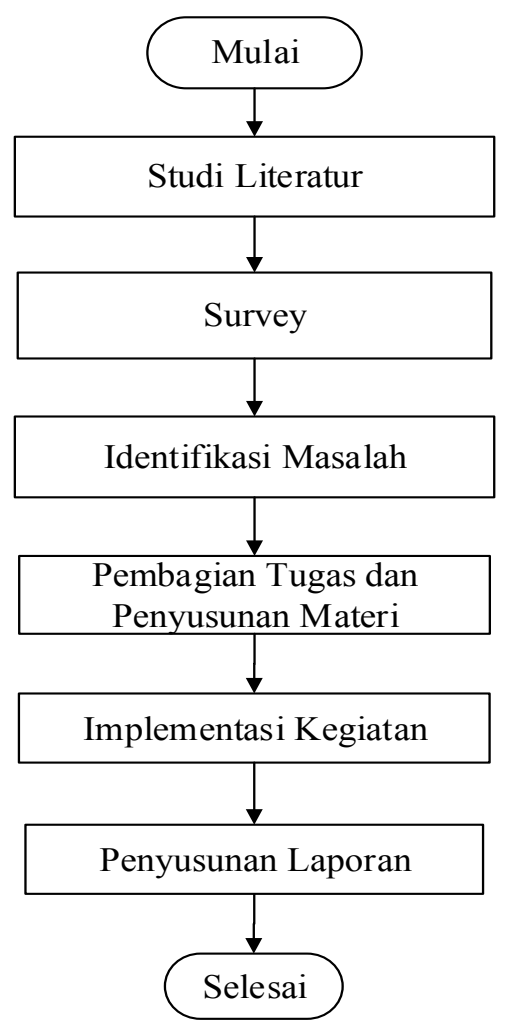

Gambar 1. Diagram alir pelaksanaan kegiatan 
a. Studi Literatur

Pada tahap ini, dilakukan pengkajian terhadap berbagai sumber mengenai trend perkembangan teknologi terhadap anak dalam era globalisasi dan bagaimana pengaruhnya terhadap perkembangan anak. Sumber kajian diperoleh melalui berbagai sumber yang ada di internet.

b. Survey

Tim pengabdian melakukan survey ke Sekolah Dasar yang ada di Kota Mataram yang akan dijadikan lokasi pelaksanaan kegiatan pengabdian. Dari survey didapatkan kesimpulan bahwa perlu diperkenalkan kepada siswa mengenai bidang komputer dengan cara yang menarik.

c. Identifikasi Masalah

Tim pengabdian melakukan observasi dan wawancara terhadap siswa kelas 4 dalam menggunakan dan memanfaatkan teknologi yang ada pada saat ini.

d. Pembagian Tugas dan Penyusunan Materi

Untuk dapat melaksanakan kegiatan ini, tim terlebih dahulu berkoordinasi untuk menentukan waktu pelaksanaan kegiatan, pembagian tugas dan peran masing-masing anggota serta penyusunan materi pengabdian. Tim menghubungi atau berkoordinasi dengan pihak Sekolah dalam hal ini diwakili oleh salah satu guru untuk mewakili sekolah untuk memberikan informasi kesediaan sebagai tempat kegiatan. Setelah mendapatkan ijin, tim menyiapkan surat dan bersurat kepada Kepala Sekolah untuk menentukan jadwal kegiatan pengabdian. Persiapan lainnya adalah diskusi dengan tim pengabdian untuk menyusun materi kegiatan.

\section{e. Implementasi Kegiatan}

Pendekatan yang dilakukan yaitu dengan melakukan pendekatan eksplorasi, dengan harapan siswa dapat mencoba, memodifikasi dan selanjutnya dapat berkreasi dengan menggunakan perangkat lunak Scratch. Siswa akan diperkenalkan algoritma dan pemrograman berbantuan komputer, siswa diajarkan bagaimana mengoperasikan perangkat lunak Scratch, mendorong siswa untuk menerapkan logika dan algoritma pada aplikasi Scratch. Tahap-tahap pendekatan yang dilakukakan yaitu siswa akan diajari dasar-dasar pemrograman, diawali dengan pengertian algoritma dan pemrograman, pengenalan perangkat lunak pemrograman Scratch, diikuti dengan pemaparan disertai contoh-contoh pengembangan game (permainan) menggunakan Scratch. Selain itu akan dipraktekkan bagaimana mengendalikan drone dengan menggunakan aplikasi Scratch.

Dengan adanya pandemi COVID-19, perilaku siswa-siswi sekolah dasar harus dirubah untuk selalu mempraktikkan cara hidup sehat dengan memperhatikan protokol kesehatan. Pada kegiatan ini, akan diberikan juga penyuluhan terkait dengan protokol kesehatan yang menitikberatkan pada praktik $3 \mathrm{M}$, yaitu mencuci tangan, memakai masker dan menjaga jarak. Sebelum dan sesudah pemberian materi, dilakukan pemberian kuesioner pra dan pasca pemberian materi untuk mengukur tingkat penerimaan dan pemahaman perserta selama pemberian materi [11].

Rencana kegiatan yang akan dilakukan adalah sebagai berikut:

1. Memberikan penyuluhan pentingnya $3 \mathrm{M}$.

2. Mengisi kuesioner pra kegiatan yang dilakukan dengan menyenangkan.

3. Pengenalan algoritma dan pemrograman dan fungsi-fungsi dasar pada program Scratch.

4. Praktik mengendalikan drone dari aplikasi Scratch.

5. Mengisi kuesioner pasca kegiatan.

\section{HaSil dan Pembahasan}

Pelaksanaan kegiatan dilaksanakan dengan melakukan kunjungan ke sekolah SDN 13 Mataram dengan sebelumnya melakukan koordinasi dengan pihak sekolah. Langkah-langkah pelaksanaan kegiatan dilakukan berdasarkan rencana kegiatan yang telah dilakukan. Uraian pelaksanaan kegiatan dapat dilihat pada poin-poin berikut ini :

1. Penyuluhan pentingnya $3 \mathrm{M}$.

Penyuluhan protokol kesehatan dengan menekankan pada $3 \mathrm{M}$, yaitu mencuci tangan, memakai masker dan menjaga jarak. Penyuluhan diawali dengan mempraktikkan cara mencuci tangan yang benar. Siswa-siswa dipandu untuk mencuci tangan dengan cara yang benar. 


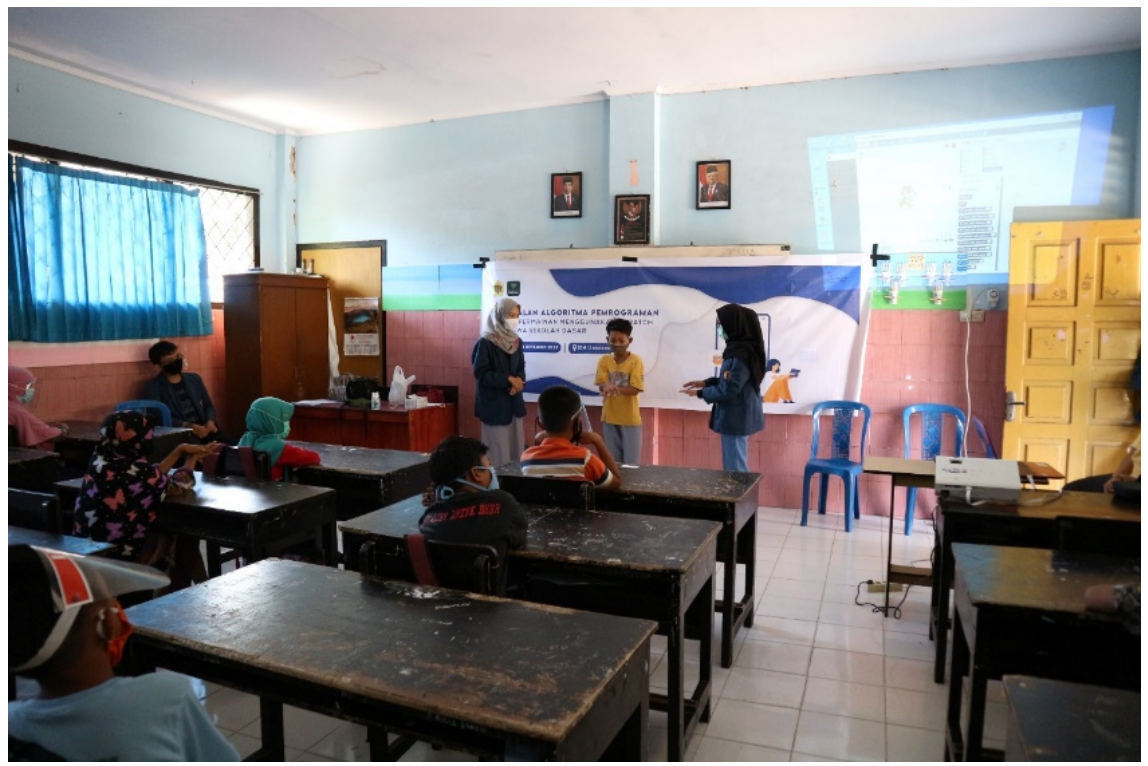

Gambar 2. Mahasiswa membimbing siswa siswi mempraktikkan cuci tangan yang benar.

2. Pengisian kuesioner awal

Sebelum memulai pemberian materi pengenalan Algoritma dan Pemrograman, siswa-siswi diarahkan untuk mengisi kuesioner awal untuk mengukur pengetahuan siswa-siswi mengenai Algoritma dan Pemrograman.

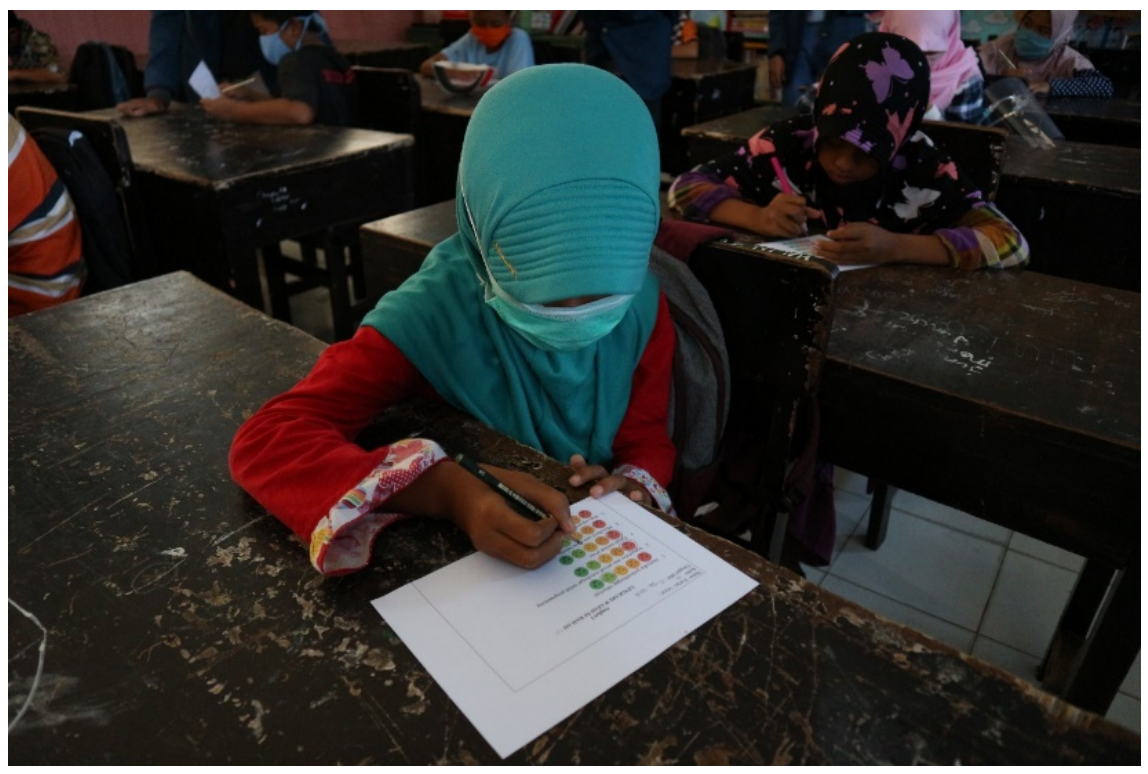

Gambar 3. Siswi mengisi kuesioner yang diberikan.

3. Pemberian materi pengenalan Algoritma Pemrograman.

Pemberian materi pengenalan Algoritma dan Pemrograman kepada siswa-siswi dengan menggunakan contoh-contoh yang mudah dimengerti. Siswa-siswi diberikan pemahaman bahwa suatu komputer tidak dapat melakukan sesuatu tanpa diberikan perintah. Perintah ini dapat diberikan dengan memberikan langkah-langkah yang merupakan algoritma penyelesaian suatu permasalahan dan pemrograman untuk mengimplementasikan algoritma tersebut. Untuk dapat melihat proses algoritma dan pemrograman, diperkenalkan aplikasi Scratch yang dapat membantu memberikan pemahaman dengan visualisasi. Siswa-siswi diperkenalkan dengan fiturfitur yang ada pada Scratch dan diberikan contoh sederhana penggunaan Scratch. 


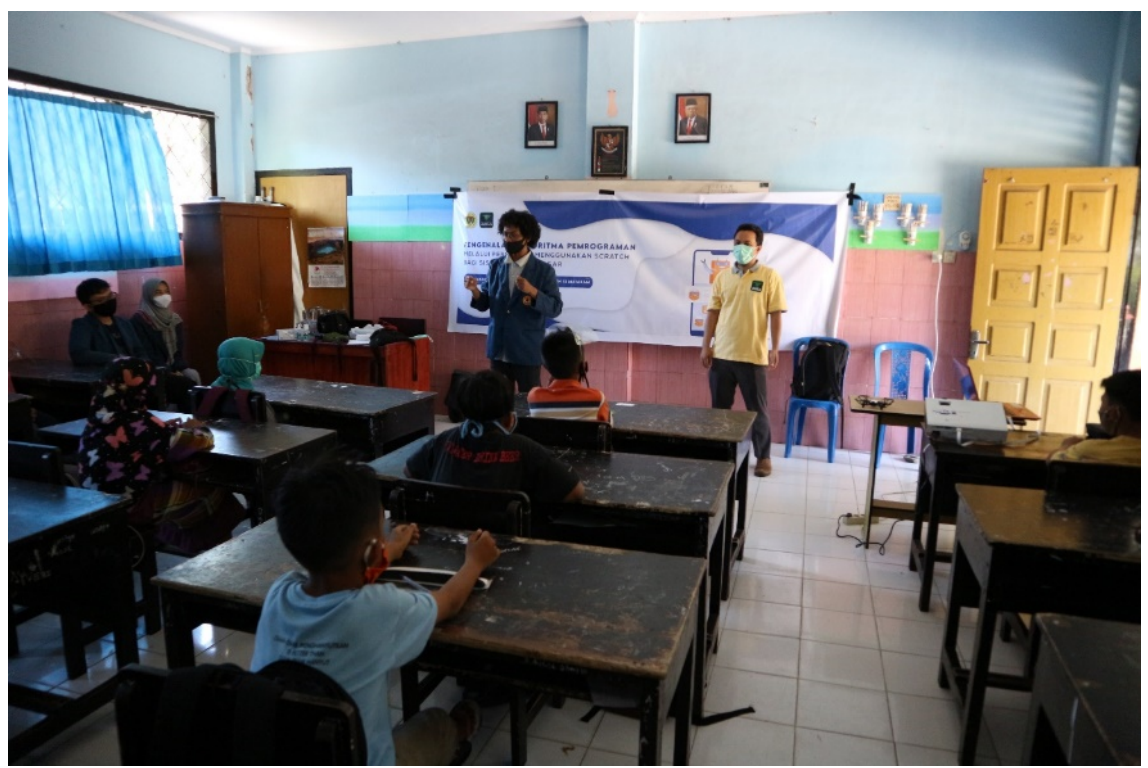

Gambar 4. Pemberian materi pengenalan Algoritma dan Pemrograman.

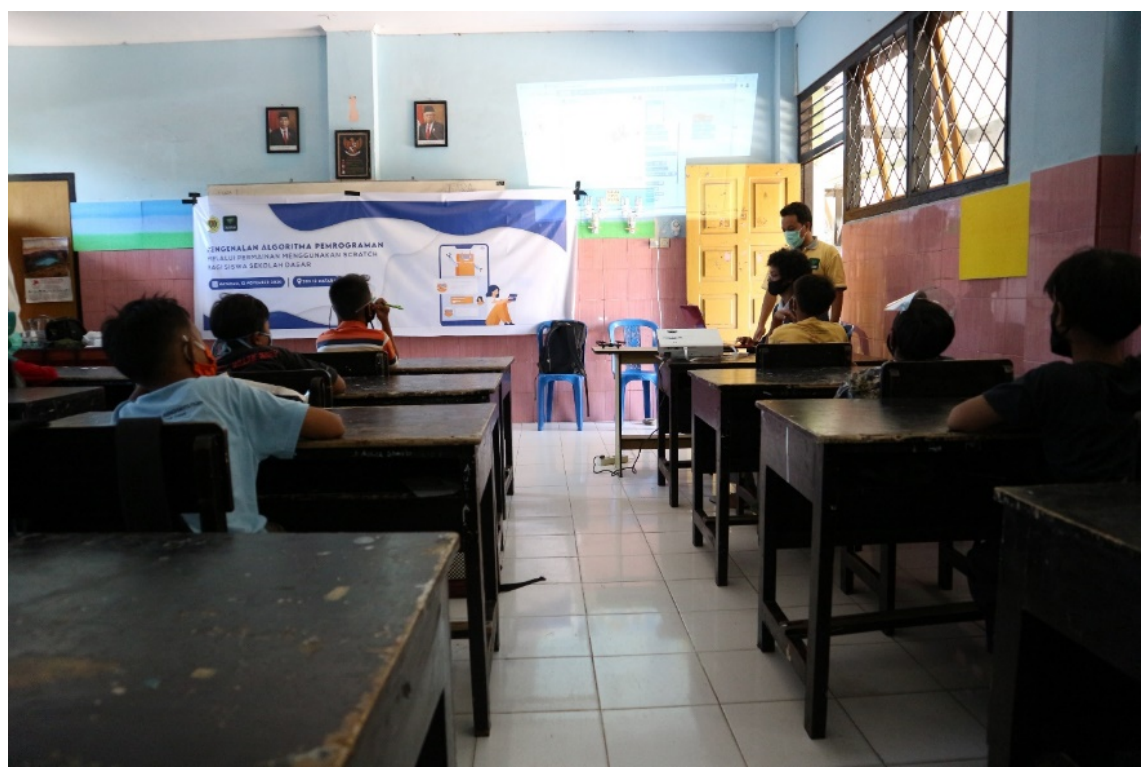

Gambar 5. Pengenalan fitur-fitur aplikasi Scratch.

4. Praktik mengendalikan drone dengan Scratch.

Untuk mempermudah siswa-siswi memahami algoritma pemrograman, maka dilakukan percobaan mengendalikan drone dengan menggunakan Scratch. Praktik dilakukan dengan mencoba mengendalikan drone dari aplikasi Scratch dengan perintah terbang, naik, turun, maju, mundur dan mendarat. Drone terlebih dahulu disambungkan dengan laptop melalui media wi-fi, kemudian mengatur langkah-langkah yang akan dieksekusi oleh drone, melalui aplikasi Scratch. Berbagai gerakan dari drone dapat diatur langkah demi langkah melalui aplikasi Scratch. Setelah dilakukan langkah ini, dilakukan sesi pertanyaan dengan memberikan pertanyaan terkait materi kepada siswa dan siswi. Jika berhasil dijawab dengan benar, maka akan diberikan hadiah. 


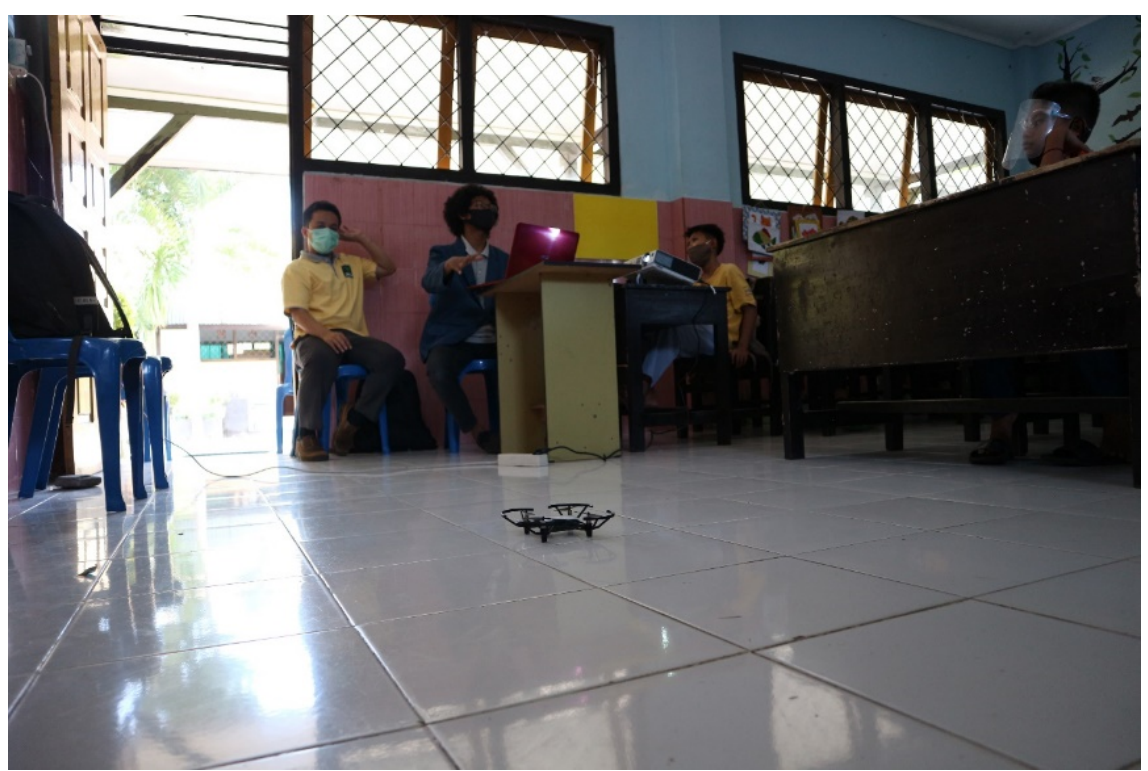

Gambar 6. Praktik menerbangkan drone dengan aplikasi Scratch.

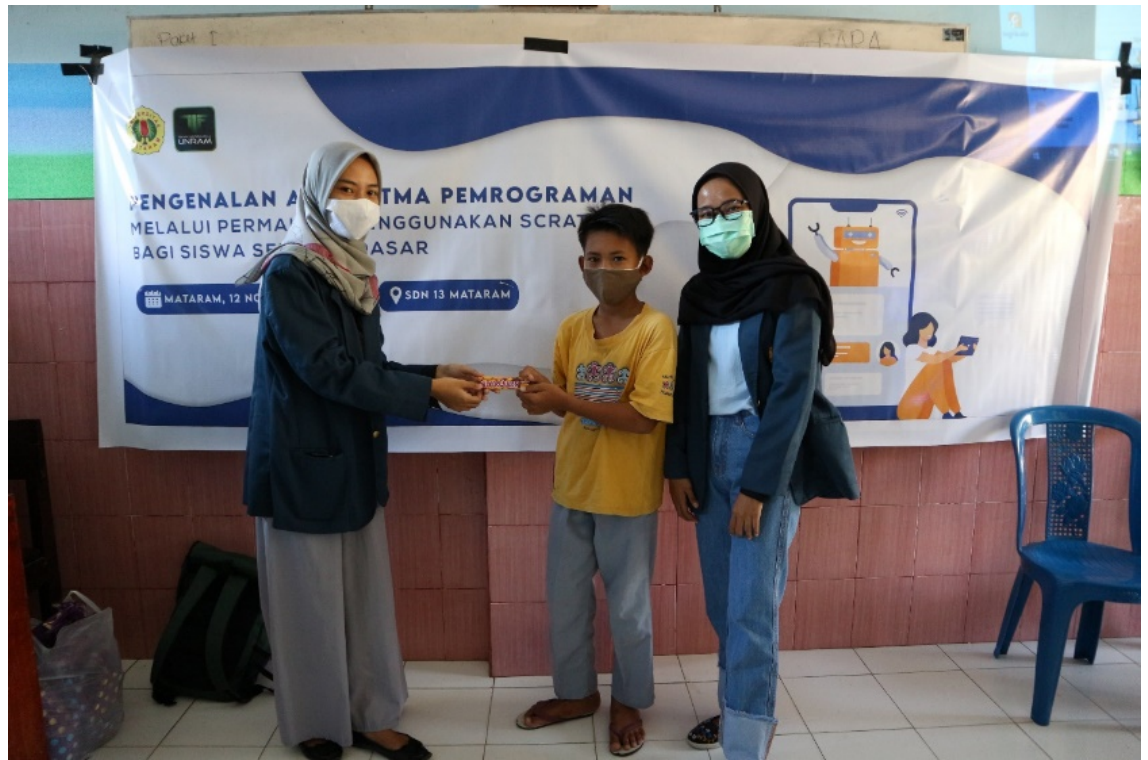

Gambar 7. Pemberian hadiah bagi siswa yang menjawab dengan benar.

5. Mengisi kuesioner akhir

Pada langkah terakhir, siswa siswi diarahkan untuk mengisi kuesioner akhir dengan pertanyaan yang sama dengan kuesioner awal untuk melihat perkembangan pengetahuan siswa siswi setelah dilakukan pengenalan algoritma dan pemrograman. Pada akhir kegiatan, dilakukan pembagian masker kepada siswa siswa SD. 


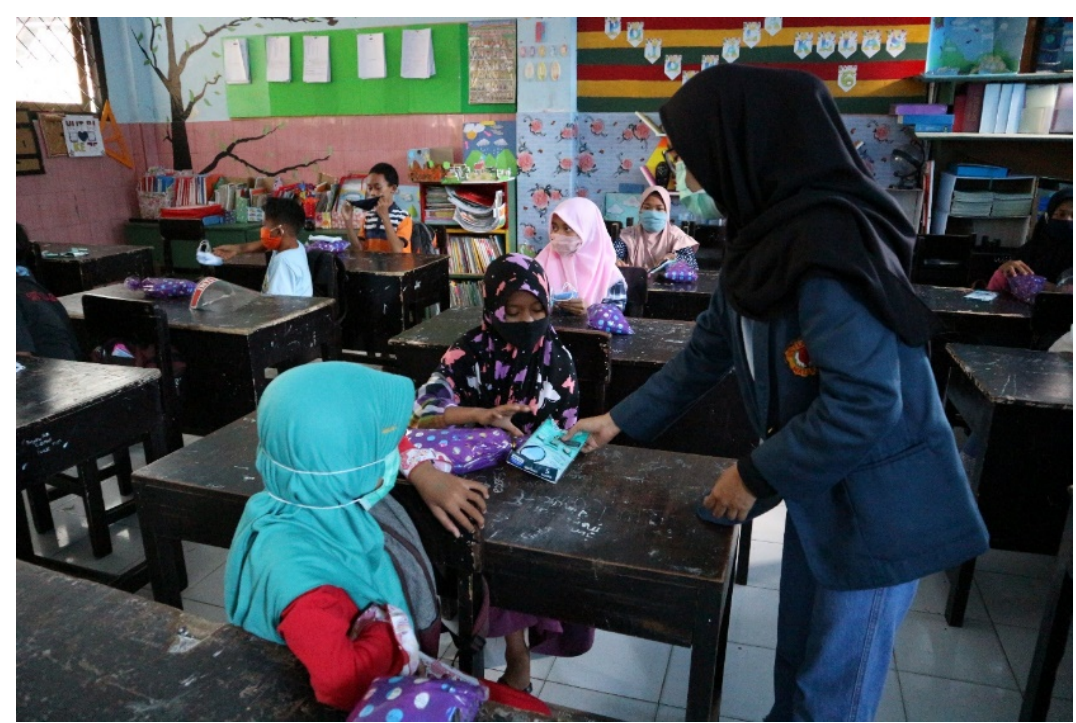

Gambar 8. Pembagian masker kepada siswa siswi

Kuesioner diberikan untuk mengukur kemampuan siswa siswa sebelum dan sesudah pemberian materi. Pertanyaan-pertanyaan yang diberikan dapat dilihat pada Tabel 1.

TABEL I. DAFTAR PERTANYAAN KUESIONER

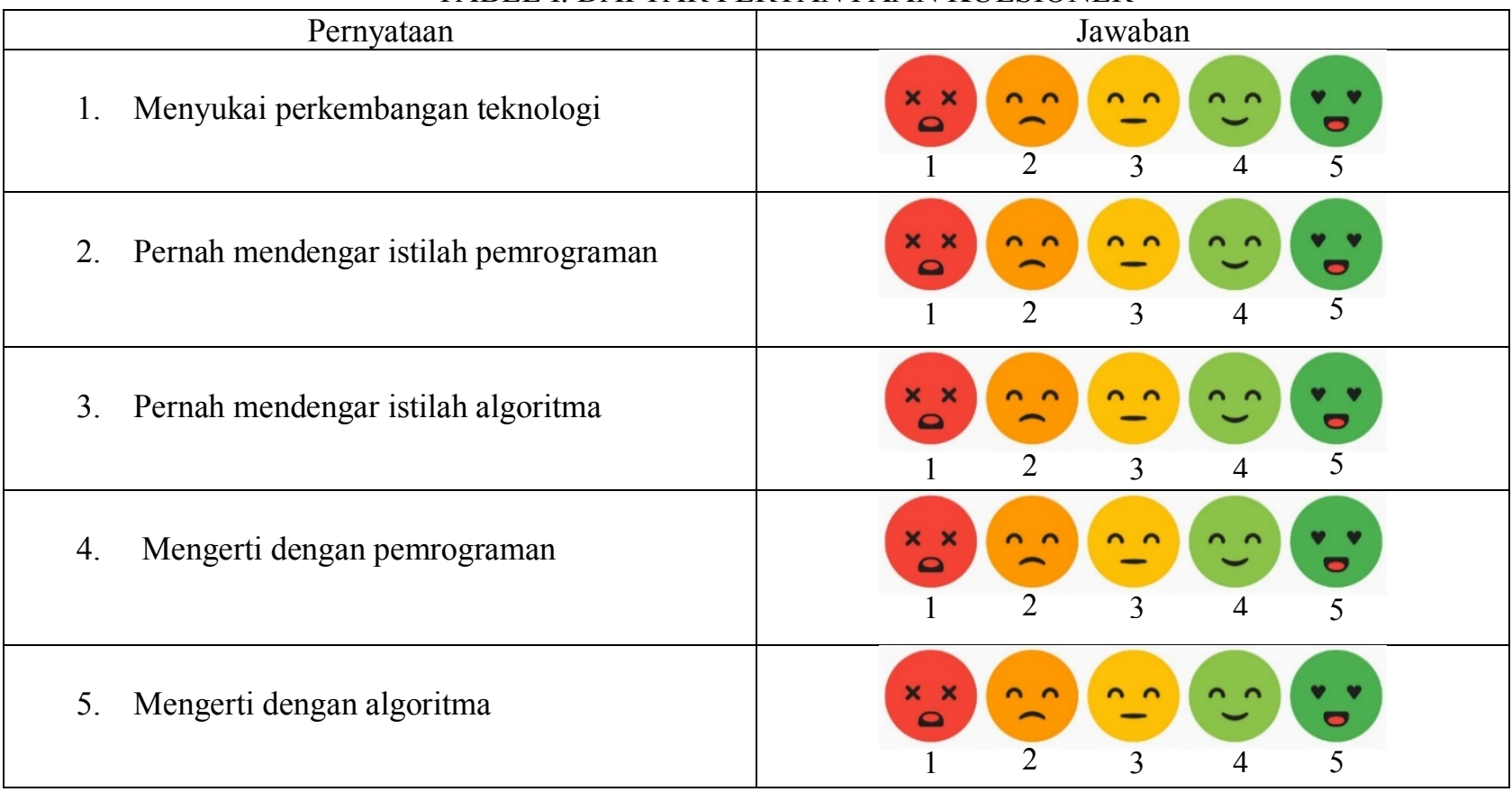

Gambar 9 merupakan hasil pemetaan jawaban siswa siswi pada kuesioner sebelum dan sesudah pemberian materi. Hasil kuesioner pra pelatihan dan pasca pelatihan memperlihatkan bahwa terdapat peningkatan pemahaman dan pengetahuan siswa mengenai algoritma pemrograman setelah dilakukan penyampaian materi. Siswa - siswi juga memiliki ketertarikan yang tinggi mengenai teknologi khususnya teknologi informasi. Praktik yang dilakukan dengan melibatkan drone juga menaikkan antusiasme siswa untuk mengikuti materi sampai selesai. Dari 15 siswa, seluruhnya tidak mengerti algoritma dan pemrograman sebelum dilakukan kegiatan dan meningkat sebanyak $80 \%$ mengerti setelah dilakukan kegiatan. Begitupun untuk ketertarikan terhadap teknologi, terjadi peningkatan siswa yang tertarik dari yang awalnya 55\% meningkat menjadi $82 \%$. 


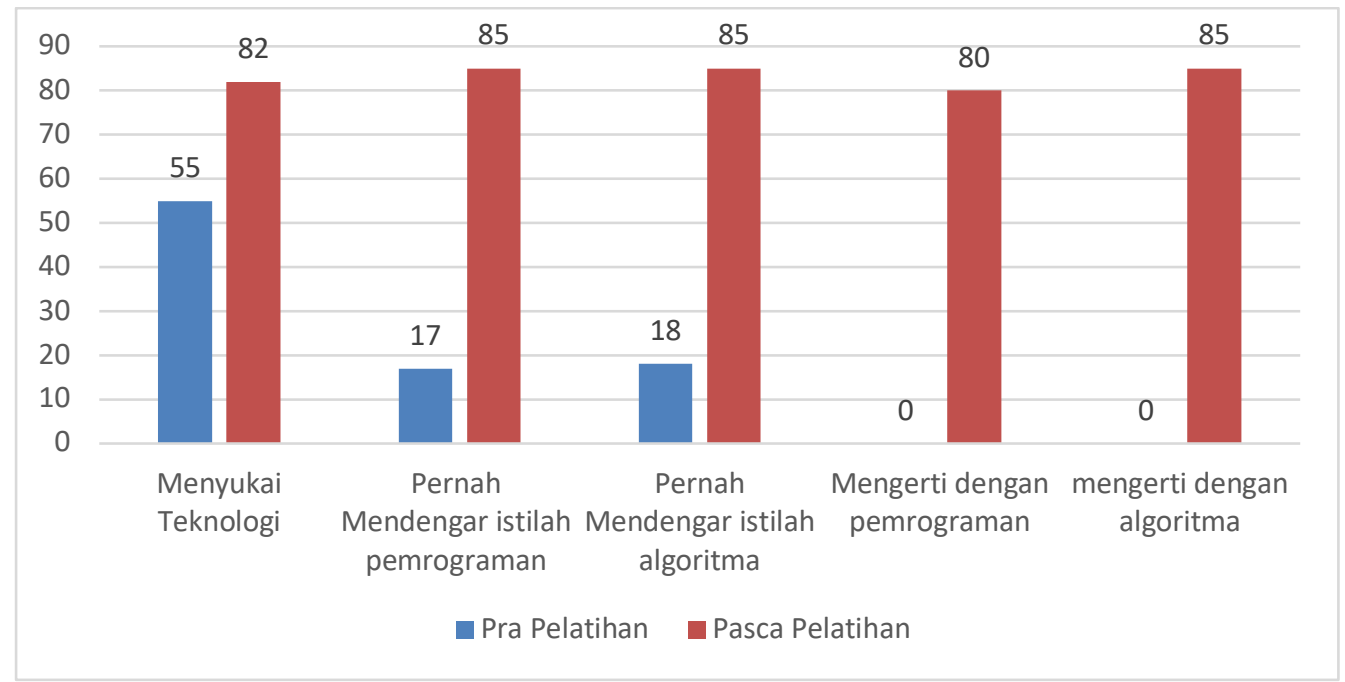

Gambar 9. Hasil kuesioner

\section{KESIMPULAN DAN SARAN}

Dari kegiatan yang sudah dilakukan, dapat ditarik kesimpulan, yaitu :

1. Siswa siswa sangat tertarik dengan materi yang disampaikan, khususnya dengan adanya teknologi terbaru yang ditampilkan.

2. Terdapat peningkatan pengetahuan dan pemahaman siswa siswi setelah dilakukan pemberian materi.

\section{UCAPAN TERIMA KASIH}

Ucapan terima kasih disampaikan kepada LPPM Universitas Mataram yang telah mendanai kegiatan pengabdian ini melalui skema pendanaan DIPA BLU Universitas Mataram.

\section{DAFTAR PUSTAKA}

[1] Sindo, "Sudah Waktunya Ada Mata Pelajaran Coding di Sekolah," sindonews, 2018. https://edukasi.sindonews.com/berita/1293593/144/sudah-waktunya-ada-mata-pelajaran-coding-di-sekolah (accessed Dec. 20, 2020).

[2] W. Juwono, "Survei Microsoft: Siswa Indonesia Ingin Belajar Coding di Sekolah," pcplus, 2015. https://www.pcplus.co.id/2015/03/survei-microsoft-siswa-indonesia-ingin-belajar-coding-di-sekolah/ (accessed Dec. 20, 2020).

[3] M. I. Rosyadi, "Mulai Tahun Depan, Anak SD di Singapura Wajib Belajar Coding," detikcom, 2019. https://inet.detik.com/cyberlife/d-4621722/mulai-tahun-depan-anak-sd-di-singapura-wajib-belajar-coding (accessed Dec. 20, 2020).

[4] A. Goel, "What is Programming," hackr.io, 2021. https://hackr.io/blog/what-is-programming (accessed Dec. 25, 2020).

[5] Futurelearn, "What is Programming," futurelearn.com, 2019. https://www.futurelearn.com/info/courses/programming-101/0/steps/43783 (accessed Dec. 25, 2020).

[6] A. Raditya and A. Baist, "Pemrograman dengan Scratch." Universitas Muhammadiyah Tangerang, 2018.

[7] J. L. Ford, Scratch Programming for Teen, 2nd ed. Boston: Cengage Learning, 2014.

[8] Toheri and Nuraenafiash, "Pengaruh Penggunaan Scratch Terhadap Kreativitas Berfikir Matematis," Eduma, vol. 2, no. $1,2013$.

[9] Zafwianur, "Penerapan Media Scratch Pada Materi Diagram Momen, Diagram Normal, Gaya Lintang di Kelas XI SMK Negeri 3 Jombang,” J. Kaji. Pendidik. Tek. Bangunan, vol. 2, no. 2, pp. 117-123, 2017.

[10] S. Sutikno, S. Susilo, W. Hardiyanto, V. Mts, M. N. Ketanggungan, and K. Kunci, "Pelatihan Pemanfaatan Scratch Sebagai Media Pembelajaran," Rekayasa, vol. 16, no. 2, pp. 173-178, 2019, doi: 10.15294/rekayasa.v16i2.17508.

[11] A. Y. Astuti and Sugianti, "Workshop Pembelajaran Teknologi Multimedia Untuk Guru SDN 4 Cepoko Kecamatan Ngrayun Guna Pengembangan Bahan Ajar,” J. Adimas, vol. 3, no. 1, pp. 30-36, 2019. 